\title{
The Treatment of the Cubital Tunnel Syndrome Using the Anterior Transposition Surgical Technique
}

Catalin Gheorghe BEJINARIU', Laura Mihaela BOGHIAN', Siramona POPESCU', Silviu Adrian MARINESCU

\begin{abstract}
Introduction: The paper aims to present the advantages and disadvantages related to using the anterior transposition technique for the treatment of the cubital tunnel syndrome. Materials and Methods: The study presents the surgical treatment of a 58 years old woman. The therapeutic protocol included the decompression of the ulnar nerve at the level of the elbow, followed by the anterior transposition, the new position being maintained by anchoring in a fascial sling. Results: The electromyographic evaluation performed 12 months after the surgical intervention indicated that the parameters of motor nerve conduction were within normal limits on all segments, normal sensory velocities from the $V$ finger, orthodromic and from the dorsal branch, sign of a very good postoperative recovery. Conclusions: Anterior transposition of the ulnar nerve may be a firm solution for the treatment of the compressive ulnar neuropathies located at the level of the elbow.
\end{abstract}

Keywords: cubital tunnel syndrome, ulnar nerve transposition, compression syndrome, fascial sling.

\section{Rezumat}

Introducere: Lucrarea de față își propune să prezinte avantajele și dezavantajele tratamentului sindromului de tunel cubital prin tehnica transpoziționarii anterioare. Materiale și metode: Studiul prezintă tratamentul chirurgical în cazul unei paciente în varstă de 58 de ani. Protocolul terapeutic a inclus decomprimarea nervului ulnar la nivelul cotului, urmată de transpoziționarea anterioară și menținerea poziției prin ancorarea într-un ham fascial. Rezultate: Evaluarea electromiografică efectuată la 12 luni de la efectuarea intervenției chirurgicale a evidențiat existența parametrilor de conducere motorie în limite normale pe toate segmentele, viteze senzitive normale din degetul $V$, ortodromic și din ramul dorsal, semn al unei recuperări postoperatorii foarte bune. Concluzii: Transpoziția anterioară a nervului ulnar poate reprezenta o soluție fermă pentru tratamentul neuropatiilor ulnare compresive localizate la nivelul cotului.

Cuvinte-cheie: sindrom de tunel cubital, transpoziția anterioară a nervului ulnar, sindrom compresiv, ham fascial.

\footnotetext{
1 Department of Plastic and Reconstructive Surgery, „BagdasarArseni" Emergency Clinical Hospital, Bucharest, Romania
}

\section{Corresponding author.}

Catalin Gheorghe BEJINARIU, Department of Plastic and Reconstructive Surgery, „Bagdasar-Arseni” Emergency Clinical Hospital, Bucharest, Romania.

E-mail: drbejinariu@gmail.com 


\section{INTRODUCTION}

Compressive neuropathies are frequently identified in advanced stages because of nonspecific symptoms which can often create difficulties in establishing the diagnosis. Nevertheless performing the electromyogram is an essential element that contributes to establishing the diagnosis ${ }^{1}$, representing the primary factor that determines the surgical protocol.

The issue of compression neuropathies is a topical subject in the context in which an increasing number of people perform their professional activity in front of computers. The repeated movements necessary for the input of data in the operating systems and the fixed positions maintained for long periods of time are also elements that contribute to the onset of these diseases and at the same time are aggravating factors for the patients with genetic predisposition related to the development of this type of diseases ${ }^{2}$.

\section{MATERIALS AND METHODS}

The paper presents the case of a 58 years old patient admitted at the 'Bagdasar-Arseni' Emergency Clinical Hospital for the treatment of left cubital tunnel syndrome. The patient had paresthesia in the fingers IV and V, the symptomatology being installed about 2 years before the admittance to the hospital. Performing the electromyography revealed the electrophysiological aspect compatible with the chronic neuropathy of the left ulnar nerve, predominantly sensitive proximal to the Guyon canal. The electrophysiological changes identified were the main factors that established the surgical indication.

The therapeutic protocol included the decompression of the ulnar nerve at the level of the elbow, its anterior transposition and the maintenance of the new anatomical relationships through the creation of an anterior fascial sling (Figure 1).

The closure of the postoperative wound was performed by an intradermal suture, a special attention being given to the atraumatic manipulation of the wound edges, as well as the dissected fascia structures, an attitude that significantly contributes to the improvement of the postoperative aesthetic aspect (Figure 2).

The surgery was performed using general anesthesia, the total duration of the procedure being 90 minutes. The patient was discharged after 2 days in the process of healing with the recommendation of administering B-complex vitamins for 30 days after the surgical intervention. The postoperative monitoring period was 2 years, the patient being reassessed every 4 months.

\section{RESULTS}

Following the surgical treatment the local evolution was favorable, the sutures being removed 14 days after the intervention. The intensity of the symptomatology diminished progressively, the patient appreciating the complete recovery approximately 45 days after the surgical treatment. Objectively, the result of the surgery was appreciated by performing an electromyography 12 months after the surgery, its result reflecting the improvement of the transmission velocity of the nerve impulses after decompression and transposition of the ulnar nerve.

Regarding the aesthetic results, the intradermal suture contributed to the improvement of the scar quality, the patient being satisfied with the postoperative aspect.
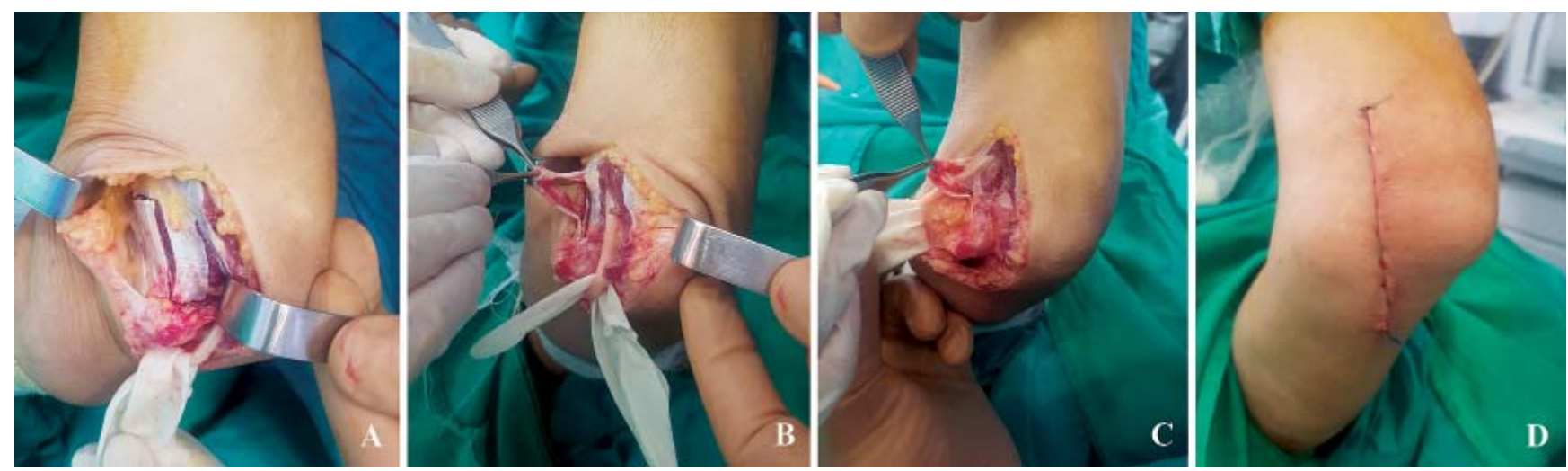

Figure 1. The stages of the surgical treatment of the cubital tunnel syndrome (left elbow). A. Muscle fascia sectioning; B. Fascial sling dissection; C. Transposition of the ulnar nerve; D. Intradermal suture. 


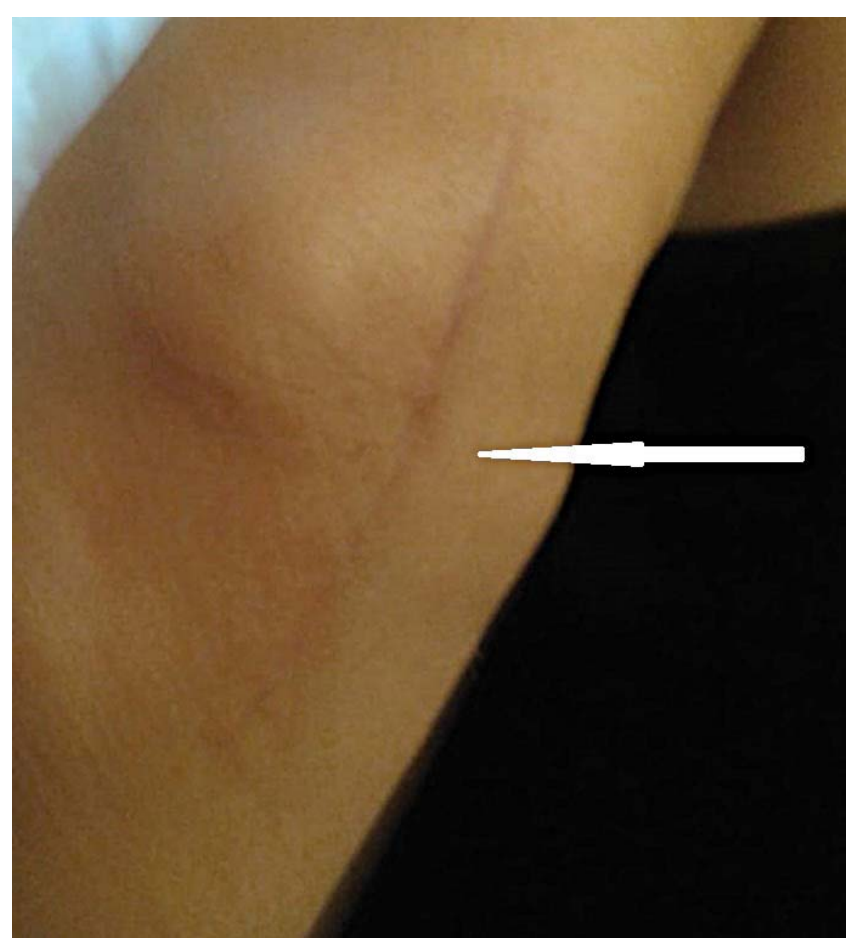

Figure 2. Postoperative aspect 6 months after the surgical intervention.
The essential therapeutic element is the decompression which contributes significantly to the recovery of the affected nerve structures ${ }^{11-13}$. In order to maintain long-term results, the transposition of nerves into positions that do not expose to risk is an extremely important aspect ${ }^{14}$.

Conducting in-depth studies on the objective analysis related to the results of the surgical treatment is often difficult, because of the patients' reluctance to perform an additional investigation (EMG) under the condition of remitted symptomatology. Therefore, most studies are based on the subjective assessment of the surgical results according to the questionnaires that assess the patients' degree of satisfaction.

\section{CONCLUSIONS}

The decompression and transposition of the ulnar nerve can be a firm solution for the treatment of cubital tunnel syndrome (at the level of the elbow), associated with a significant improvement in the velocity of the nerve impulses (objectified through EMG), as well as with a high degree of patient satisfaction related to the postoperative result.

Regarding the aesthetic result, performing the surgery by atraumatic manipulation of the involved anatomical structures, rigorous hemostasis and performing an intradermal suture are all elements that contribute to minimizing the size of the scar with a major impact on increasing the level of the patient satisfaction.

Compliance with ethics requirements: The authors declare no conflict of interest regarding this article. The authors declare that all the procedures and experiments of this study respect the ethical standards in the Helsinki Declaration of 1975, as revised in 2008(5), as well as the national law. Informed consent was obtained from all the patients included in the study.

\section{References}

1. Staples JR, Calfee R. Cubital Tunnel Syndrome: Current Concepts. Journal of the American Academy of Orthopaedic Surgeons. 2017; 25(10):215-224

2. Andrews K, Rowland A, Pranjal A et al. Cubital tunnel syndrome: Anatomy, clinical presentation, and management. Journal of Orthopaedics. 2018; 15(3): 832-836.

3. Mooneya M, Andrewsa K, Rowland A, et al. Clinical outcomes of combined surgical treatment of medial epicondylitis and cubital tunnel syndrome. Hand Surgery and Rehabilitation. 2019; 38(5):298-301.

4. Foran I, Vaz K, Sikora-Klak J. Regional Ulnar Nerve Strain Following Decompression and Anterior Subcutaneous Transposition in Patients With Cubital Tunnel Syndrome. The Journal of Hand Surgery. 2016; 41(10):343-350.

5. Osei DA, Groves AP, Bommarito K et al. Cubital Tunnel Syndrome: Incidence and Demographics in a National Administrative Database. Neurosurgery. 2017; 80(3):417-420.

6. Boone S, Gelberman RH, Calfee RP. The Management of Cubital Tunnel Syndrome. The Journal of Hand Surgery. 2015 40(9):1897-1904 
7. Bejinariu CG, Marinescu SA, Enescu DM, The Romanian National Breast Reconstruction Program - Results and Conclusions after 5 Years. Modern Medicine. 2019;26(1):23-30.

8. Speach DP, Lee DJ, Reed JD. Is medial elbow pain correlated with cubital tunnel syndrome? An electrodiagnostic study. Muscle\&Nerve. 2016; 53(2):252-254.

9. Marinescu SA, Bejinariu CG, Giuglea C, Research Related to Breast Implant-associated Anaplastic Large Cell Lymphoma and its Influence on the Decision-Making Process Related to Reconstructive Techniques Analysis of a series of cases and literature review. Mat Plast, 2019; 56(1):229-234.

10. Gaspar MP, Kane PM, Putthiwara D. Predicting Revision Following In Situ Ulnar Nerve Decompression for Patients With Idiopathic Cubital Tunnel Syndrome. The Journal of Hand Surgery. 2016; 41(3):427-435.
11. Brady C, Dutta A. Medial Epicondylitis and Medial Elbow Pain Syndrome: Current Treatment Strategies. J Musculoskelet Disord Treat. 2016; 2(2):1-5.

12. Bejinariu C, Apostolescu I, Marinescu S, Tratamentul cicatricilor postcombustionale de la nivelul sânului. Romanian Journal of Medical Practice. 2019; 14(1):62-65.

13. Tawfik MR, Khedr WM, Sakr MF. Comparative Study of Outcome of Simple Decompression Versus anterior Transposition of Ulnar Nerve in the Treatment of Cubital Tunnel Syndrome. National Journal of Health Sciences. 2017; 2:52-56.

14. Frantz LM, Adams JM, Granberry S. Outcomes of ulnar nerve anterior transmuscular transposition and significance of ulnar nerve instability in cubital tunnel syndrome. Journal of Shoulder and Elbow Surgery. 2019; 28(6):1120-1129. 